Collection: RegioResources 21 - "Spatial information and participation of socioecological systems: experiences, tools and lessons learned for land-use planning" Guest Editor: Daniele La Rosa, Carsten Lorz, Hannes Jochen König, Christine Fürst

\section{Future land use and food security scenarios for the Guyuan district of remote western China}

\author{
Lin Zhen ${ }^{(1)}$, Xiangzheng Deng ${ }^{(2)}$, Yunjie Wei ${ }^{(1)}$, Qunou Jiang ${ }^{(3)}$, Yingzhi \\ Lin ${ }^{(2)}$, Katharina Helming ${ }^{(4)}$, Chao Wang ${ }^{(1)}$, Hannes Jochen König ${ }^{(4)}$, Jie \\ $\mathrm{Hu}{ }^{(1)}$
}

Government policy is a major human factor that causes changes in land use. Decisions on land management and land-use planning, as well as the analysis and quantification of policy consequences, may greatly benefit from the simulation of the dynamics of land-use systems. In the present study, we predicted land-use changes and their potential impacts on food security in the environmentally fragile Guyuan District, Ningxia Hui Autonomous Region (north-central China), under the influence of a program to convert sloping agricultural land to conservation uses. Baseline and conservation policy scenarios (2005 to 2020) were developed based on input from local stakeholders and expert knowledge. For the baseline and conservation policies, we formulated high-, moderate-, and low-growth scenarios, analyzed the driving mechanisms responsible for the land-use dynamics, and then applied a previously developed "dynamics of land systems" model to simulate changes in land uses based on the driving mechanisms. We found that spatially explicit policies can promote the conversion of land to more sustainable uses; however, decreasing the amount of agricultural and urban land and increasing grassland and forest cover will increase the risk of grain shortages, and the effect will be more severe under the conservation and high-growth scenarios than under the baseline and low-growth scenarios. The Guyuan case study suggests that, during the next decade, important tradeoffs between environmental conservation and food security will inevitably occur. Future land-use decisions should carefully consider the balance between land resource conservation, agricultural production, and urban expansion.

Keywords: Land-use Patterns, Scenario Analysis, Dynamics of Land Systems Modeling, Food Security, Guyuan District, North-central China

\section{Introduction}

"Land use" is understood to mean human activities that exhibit a spatial dimension and that change the bio-geophysical conditions of land and the associated environment (Helming et al. 2008). Land use is a key factor that determines a landscape's performance with respect to socioeconomic functions such as land-based production, infrastructure, and housing (Mander et al. 2007). Significant changes in land use and land management have taken place in China since 1978 , and one of the most important drivers of these changes has been human intervention through the implementation of land-use policies. One particularly dramatic example is the Sloping Land Conversion Program (SLCP), the initial phase of China's Grain for Green program, which was initiated in 1999 by the State Council (1998) and which was fully implemented in 2000. Excessive reclamation of land for agriculture in environmentally fragile frontier regions had led to a series of natural disasters (Lin \& Samuel 2003). For instance, severe flooding in areas surrounding the Yangtze River in 1998 caused an economic loss of respectively 13.5 billion RMB (renminbi) in Shandong Province and 156.8 billion RMB (US\$ 19.6 billion) overall, and at least 1526 people died (Zhang \& Yang 1998, Li 1999, Jiang \& Shi 2003). In response, the Chinese government realized that it had become necessary to take immediate action to alleviate these water-related problems and the related soil erosion that occurred in agricultural land on steep slopes (Xu \& Cao 2001). Based on their experience with the pilot program, the government recognized that far more marginal agricultural land should be retired from agricultural use and revegetated using either trees or grassland vegetation (Du 2001). Therefo-
(1) Department of Natural Resources and Environment Security, Institute of Geographic Sciences and Natural Resources Research, Chinese Academy of Sciences, Beijing (China); (2) Center for Chinese Agricultural Policy, Institute of Geographic Sciences and Natural Resources Research, Chinese Academy of Sciences, Beijing (China); (3) School of Soil and Water Conservation, Beijing Forestry University, 100038 Beijing (China); (4) Leibniz Centre for Agricultural Landscape Research (ZALF), Eberswalder Straße 84, D-15374 Müncheberg (Germany)

@ Lin Zhen (zhenl@igsnrr.ac.cn)

Received: Oct 31, 2013 - Accepted: Nov 26, 2013

Citation: Zhen L, Deng X, Wei $Y$, Jiang Q, Lin $Y$, Helming $K$, Wang C, König HJ, Hu J, 2014. Future land use and food security scenarios for the Guyuan district of remote western China. iForest 7: 372-384 [online 2014-05-19] URL: http: / /www.sisef.it/ iforest/contents/?id=ifor1170-007

Communicated by: Marco Borghetti

re, the original program evolved into a more widespread program to combat soil erosion, alleviate the deterioration of natural ecosystems, safeguard water resources, and promote sustainable development in rural China (Tao et al. 2004).

The goal of the SLCP is to convert agricultural land on steep slopes or heavily degraded land into forest or grassland (Ramankutty et al. 2002, Feng et al. 2005), and to restore degraded forest and grassland; the ultimate goal is to prevent soil erosion by reducing the area of exposed soil. The steepness of the slope ( $15^{\circ}$ or above) is one of the main criteria for the selection of farmlands to be converted into forest or grassland. The SLCP stipulates that farmers who convert degraded farmland on steep slopes into either grassland or "ecological forests" (orchards or plantations of trees with medical value, and timber-producing forests that will not be harvested because of their role in protecting slopes) will be compensated with: (1) an annual in-kind subsidy of grain to compensate them for their lost crops; (2) a cash subsidy; and (3) free seedlings and grass seed for use in revegetation at the beginning of the planting period. To account for differences in regional average yields, the grain subsidy was set at $2250 \mathrm{~kg} \mathrm{ha}^{-1}$ in the Yangtze River Basin and $1500 \mathrm{~kg} \mathrm{ha}^{-1}$ in the Yellow River Basin. The annual cash subsidy is 300 RMB (about US\$ 44) per hectare of eligible land to pay for tending and miscellaneous expenses on the newly converted land. The grain and cash subsidies last for 8 


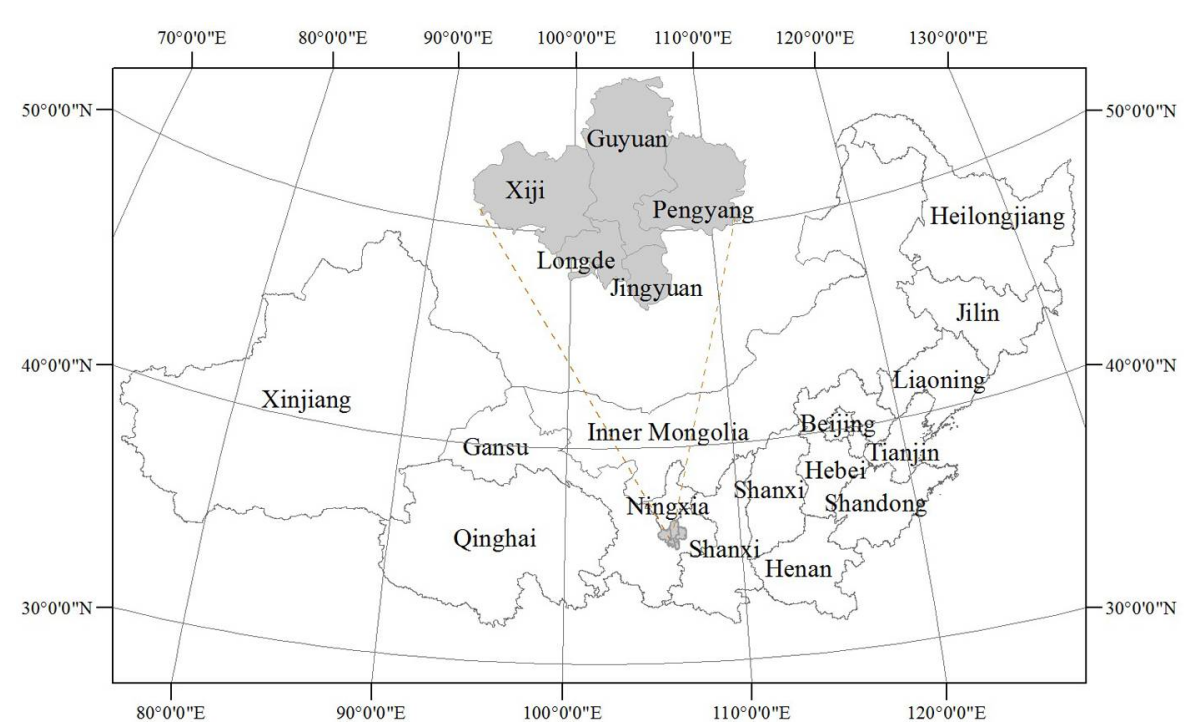

Fig. 1 - Location of the case study area, Guyuan District of the Ningxia Hui Autonomous Region.

years if ecological forests are planted and for 5 years or 2 years if economic forests or grasses are planted, respectively $(\mathrm{Xu}$ et al 2004). In addition, the SLCP provides farmers with a one-time cash subsidy of 750 RMB ha- ${ }^{-1}$ (about US\$ 110 ha $^{-1}$ ) to purchase seeds or tree seedlings for planting.

The policy has been welcomed by farmers because the cash and food compensation generally exceeded their net production, and in some cases even exceeded their gross yields on the targeted land (CCICED 2004). It is possible, however, that as arable land is converted into forest and grassland and built-up area, the loss of agricultural land will conflict with China's national food security goals. Although little was heard about this conflict in the late 1990s through 2003 , rising grain prices in early 2004 led policymakers and scholars to debate the role of these land conversions in rising food prices, and to question whether the land conversion might threaten China's food supply (Ministry of Land and Resources 2004, Feng et al. 2005). Among other responses in early 2004, the State Council addressed the importance of slowing down the conversion of natural vegetation to arable land. Some researchers believed that this policy reversal was unnecessary and could slow regional economic growth (Huang et al. 2004). Another group of scholars claimed that the change was critical to maintain national food security (Brown 1995, Verburg et al. 2000, Yang \& Li 2000).

In China, food security is looked at from both quantitative and qualitative aspects, from quantity aspect it includes three perspectives: per capita food or grains; national total quantity; and the concept of regional quantity. From quality aspect, food security implies the nutrition level that can be met from protein foods consumption. A multitude of studies have addressed the concerns raised by changes in land use. Most were based on historical observations (e.g., ParésRamos et al. 2008, Lin \& Samuel 2003, Thapa \& Rasul 2006, Yang 2006, Chen 2008), on investigations of specific land-use change processes and their driving forces in local case studies (e.g., Hao et al. 2005, Yang et al. 2005, Zhen et al. 2005, 2009), or on the loss of agricultural land and its causes ( $\mathrm{Pa}-$ rés-Ramos et al. 2008, Caradec et al. 1999, Ramankutty et al. 2002). A study of land use dynamics based on land-use inventories in Italy revealed that land conversion into forest over time was similar in magnitude to land conversion into urban areas (e.g., Corona et al. 2012). In some recent papers, König et al. $(2012,2013,2014)$ assessed the impact of the SLCP on land-use functions in the Guyuan District of the Ningxia Hui Autonomous Region of north-central China and Inner Mongolia, and found that the program had improved the environment by mitigating soil erosion, but that the region had little economic potential in non-agricultural sectors, and the bottom-up stakeholder participation is essential for ensuring successful implementation of ecosystem conservation program. In particular, the forestry sector provided only limited job opportunities to local people. Zhen et al. (2010) investigated the changing food consumption patterns and impact on land requirement as a result of SLCP. The SLCP requires integrated forest management to minimize the risk of unsustainable water consumption by agriculture while contributing economic and social benefits (König et al. 2012). There has been little or no systematic investigation of future land-use patterns and the associated impacts on food security if the SLCP continues.
Land conversion under the SLCP is determined by two primary variables: the slope of the land (i.e., its eligibility for the program) and the subsidy provided to the farmers (i.e., the incentive to participate). In the present study, our goal was to analyze land-use changes and the effects on grain production under the baseline (current) scenario and under a conservation policy scenario, each with three growth-rate scenarios for each driving factor, and to analyze the impact of the resulting land-use change on China's food security.

The paper starts with a brief introduction to the study site, the Guyuan District of northcentral China. We then describe our research methodology, including the parameters and variables used for scenario development, and provide a detailed description of the baseline and policy scenarios. We then explain the dynamics of land systems (DLS) modeling method used to predict future conditions in each scenario. We conclude by presenting the major results of our analysis and discussing their implications.

\section{Study area (Guyuan District)}

Guyuan District is located in a remote, environmentally fragile mountainous frontier region of north-central China (Fig. 1). The area has a mean annual rainfall of $483 \mathrm{~mm}$ and an annual potential evapotranspiration of 1250 to $2000 \mathrm{~mm}$, with only rain-fed agriculture possible in most of the district; however, irrigated agriculture is possible in small areas. Farmers in the area have limited resources and mostly practice subsistence agriculture. Their per capita holdings of arable land, forest, and grassland are 0.27, 0.28, and 0.31 ha, respectively, which are higher than the corresponding national averages for farmers of $0.11,0.11$, and 0.24 ha (OGC 2007). Major crops grown in the area are cereal crops such as winter wheat (Triticum aestivum), summer maize (Zea mays), and potato (Solanum tuberosum). The remaining land is used mainly for the cultivation of millet (Panicum miliaceum), buckwheat ( $\mathrm{Fa}$ gopyrum esculentum), oilseed plants (Brassica napus), oats (Avena sativa), beans (including field beans, Vicia faba; common beans, Phaseolus vulgaris; and peas, Pisum sativum), sweet potato (Ipomoea batatas), leafy green vegetables (e.g., lettuce, celery), fruit trees, and fodder crops. As of 2009, the population density was 142 persons $\mathrm{km}^{-2}$, and out of the total of 1.5 million people, some $89 \%$ of the population was employed as farmers.

\section{Methods}

\section{Dependent variables and factors}

influencing land use in Guyuan District

The original land-use map of Guyuan district was derived from Landsat TM and ETM 
Tab. 1 - List of land-use types and influencing factors considered in the Guyuan District case study.

\begin{tabular}{|c|c|c|}
\hline Factor type & Influencing factor & Definition \\
\hline \multirow{6}{*}{$\begin{array}{l}\text { Land-use } \\
\text { types }\end{array}$} & Arable land & The original data include both irrigated and non-irrigated uplands \\
\hline & Forest & $\begin{array}{l}\text { Natural or planted forests with canopy covers greater than } 30 \% \text {; land covered by trees } \\
\text { less than } 2 \mathrm{~m} \text { tall, with a canopy cover greater than } 40 \% \text {; land covered by trees with a } \\
\text { canopy cover between } 10 \text { and } 30 \% \text {; and land used for tea gardens, orchards, and } \\
\text { nurseries }\end{array}$ \\
\hline & Grassland & $\begin{array}{l}\text { Lands covered by herbaceous plants, with coverage greater than } 5 \% \text {, and mixed range- } \\
\text { land with a coverage by shrub canopies of less than } 10 \%\end{array}$ \\
\hline & Water body & $\begin{array}{l}\text { Land covered by natural bodies of water or land with facilities for irrigation and water } \\
\text { reserves, including rivers, canals, lakes, permanent glaciers, beaches and shorelines, } \\
\text { and bottomland }\end{array}$ \\
\hline & Built-up area & Land used for urban and rural settlements, as well as for industry and transportation \\
\hline & Unused land & All other land \\
\hline \multirow[t]{5}{*}{$\begin{array}{l}\text { Geophysical } \\
\text { variables }\end{array}$} & Terrain & $\begin{array}{l}\text { 0: Hills or mountains } \\
\text { 1: Plains } \\
\text { 2: Valleys and ravines } \\
\text { 3: Plateau }\end{array}$ \\
\hline & Soil $\mathrm{pH}$ value & $\mathrm{pH}$ value of the soil \\
\hline & Depth of the soil & Depth of the topsoil $(\mathrm{cm})$ \\
\hline & Elevation & Obtained from a digital elevation model (DEM, m asl) \\
\hline & Slope & Terrain slope derived from the DEM $\left(0.01^{\circ}\right.$ intervals $)$ \\
\hline \multirow{4}{*}{$\begin{array}{l}\text { Climatic } \\
\text { variables }\end{array}$} & Air temperature & Mean annual temperature $\left( \pm 0.1^{\circ} \mathrm{C}\right)$ \\
\hline & Cumulative temperature $\left(\geq 0^{\circ} \mathrm{C}\right)$ & Annually accumulated daily mean air temperature above $0^{\circ} \mathrm{C}\left( \pm 0.1^{\circ} \mathrm{C}\right)$ \\
\hline & Cumulative temperature $\left(\geq 10^{\circ} \mathrm{C}\right)$ & Annually accumulated daily mean air temperature above $10^{\circ} \mathrm{C}\left( \pm 0.1^{\circ} \mathrm{C}\right)$ \\
\hline & Hours of sunshine & $\begin{array}{l}\text { Hours of sunshine rectified to account for the spatial variability of solar radiation } \\
\text { (i.e., topographic effects) }\end{array}$ \\
\hline \multirow{3}{*}{$\begin{array}{l}\text { Proximity } \\
\text { variables }\end{array}$} & Distance to provincial capital & Geometric distance to the nearest provincial capital $(\mathrm{km})$ \\
\hline & Distance to highway & Distance to the nearest highway $(\mathrm{km})$ \\
\hline & Distance to secondary highway & Distance to the second nearest highway $(\mathrm{km})$ \\
\hline \multirow[t]{4}{*}{$\begin{array}{l}\text { Socioeconomic } \\
\text { variables }\end{array}$} & Population density & $\begin{array}{l}\text { Interpolated population density (persons } / \mathrm{km}^{2} \text { ) based on the population distribution } \\
\text { model }\end{array}$ \\
\hline & GDP & $\begin{array}{l}\text { Interpolated values of gross domestic product (GDP; } 10000 \mathrm{RMB} / \mathrm{km}^{2} \text { ) based on spa- } \\
\text { tially explicit analyses of the relationship between economic growth and factors that } \\
\text { might affect economic growth }\end{array}$ \\
\hline & Urbanization & Proportion of total population accounted for by urban residents (\%) \\
\hline & $\begin{array}{l}\text { Investment in agricultural research } \\
\text { and development }\end{array}$ & $\begin{array}{l}\text { Proportion of total investment (\%) accounted for by investment in agricultural research } \\
\text { and development }(\mathrm{R} \& \mathrm{D})\end{array}$ \\
\hline
\end{tabular}

images of the middle 2000s including the images for $2004 / 2005$ with the spatial resolution of $30 \times 30 \mathrm{~m}$. The images were processed by geometric correction, image registration, etc. using the software of ENVI (Deng et al. 2008). Land use in the study area were extracted by means of a supervised classification using the software ArcGIS $\mathbb{R}$ (ESRI, Redlands, CA, USA) based on differences in the spectral, textural, and color characteristics of the image, which were expressed by the land use code ( 1 for arable land, 2 for forest, 3 for grassland, 4 for water area, 5 for built-up area and 6 for unused land). The results of the image interpretation were then verified through field surveys; more than 200 plots in the study area were chosen to test the interpretation accuracy, proved through the kappa value. The overall precision of all kinds of land uses was more than $92 \%$. After the land use information was extracted, it was converted to the grid data with the spatial resolution of $300 \times 300$ $\mathrm{m}$. When the ground-truth observation revealed that a cell contained multiple land uses, we used the land use that covered the majority of the cell area as the land-use type in that cell. Land uses were then reclassified and expressed using a special representation scheme in which each $300 \times 300 \mathrm{~m}$ cell of the grid was expressed as a binary value (1 or 0 ) to indicate the existence or absence (respectively) of each type of land use in that cell (Deng et al. 2008).

The dynamics of a land-use system are potentially influenced by many factors. In this case study, we divided these factors into four categories: geophysical, climatic, proximity, and socioeconomic. These factors are generally accepted as determinants of the landuse distribution and as the driving factors responsible for land-use change (Turner et al. 1993). The land-use types and the influencing factors used for our analysis of the landuse change scenarios are listed in Tab. 1. All of these factors were used for simulation of our scenarios. The relationships between the binary variable for each land use and the factors influencing these land uses were identified, measured, and then considered in our simulation of land-use changes. We explored the relationships between the land uses and the factors influencing them by means of spatial regression analysis.

First of all, all of the factors were collected and processed at the pixel level with a spatial resolution of $300 \times 300 \mathrm{~m}$. Among them, the climatic data acquired from the China $\mathrm{Me}$ teorological Bureau were interpolated by means of kriging (Deng et al. 2008). Geophysical data were provided by the Data Center of the Chinese Academy of Sciences, which were all pre-made in the $300 \times 300 \mathrm{~m}$ grid level. Proximity data was estimated using national highway and provincial capital data with the software $\operatorname{ArcGIS}{ }^{\circledR}$. The spatial distribution of population density was simulated at the grid level by combining remotely sensed data, meteorological data, soil data, and statistical data by means of a gridgeneration model (Liu et al. 2002). Finally, all of the factors and land use data were inputted into the software GeoDa (Deng et al. 2008) to carry out the spatial regression analysis. 
Tab. 2 - Baseline scenario and variables.

\begin{tabular}{llrrr}
\hline Variables & Year & Low & Moderate & High \\
\hline Population density & 2010 & 135.7 & 135.7 & 138 \\
(persons km ${ }^{-2}$ ) & 2020 & 138.3 & 138.3 & 146 \\
\hline Urbanization & 2010 & 9.7 & 10.3 & 10.8 \\
(\% of population) & 2020 & 10.3 & 11.8 & 12.7 \\
\hline Investment in agricultural & 2010 & 8850.2 & 9113.4 & 9246.6 \\
R\&D (RMB) & 2020 & 17634.5 & 18835.4 & 19723.7 \\
\hline GDP & 2010 & 53.8 & 55.4 & 56.2 \\
$\left(10000 \mathrm{RMB} \mathrm{km}^{-2}\right)$ & 2020 & 107.2 & 114.5 & 119.9 \\
\hline
\end{tabular}

\section{Scenario development}

In the present study, we developed scenarios for land-use changes based on a literature review and expert judgments that relied on broad consultation with experts from the Chinese research community (e.g., the Chinese Academy of Sciences, Chinese Academy of Social Sciences, China Agricultural University, Peking University, Bureau of Survey and Mapping of China), with policymakers (e.g., the Administration for China's stry of Environmental Protection, State Bureau of Forestry), and with local decision makers (e.g., from the Commission of Development and Reform, Bureau of Agriculture, Bureau of Forestry, Bureau of Environmental Protection, Bureau of Statistics).

A list of drivers for the baseline scenarios and variables for environmental conservation policy scenario was prepared based on our knowledge and experience about the local situations. Relevant officials at the aforementioned organizations were then requested to rank the most important drivers and variables. Altogether 20 experts were involved in the interview, and a final list with main drivers for the baseline scenario and variables for the policy scenario was obtained (refer to Tab. 2 and Tab. 3). Based on these inputs, we developed three levels of growth in the driving factors, to simulate land-use changes in Guyuan District from 2005 to 2020.

\section{Baseline scenario and growth scenarios}

In the baseline scenario, we assumed that the current subsidy for participants in the SLCP will not change, and that no new areas

of sloping land will be targeted for conversion under the SLCP. We identified four main drivers for the baseline scenario: population density (persons $\mathrm{km}^{-2}$ ), urbanization trend ( $\%$ of urban population), government's investment in agricultural research and development (R\&D, in RMB), and gross domestic product (GDP) per unit land area (10 $\left.000 \mathrm{RMB} \mathrm{km}{ }^{-2}\right)$. The high-, moderate-, and low-growth rate values for each of those four drivers were estimated based on their past trends and expert judgment from the interview (Tab. 2).

\section{Environmental conservation policy sce- narios and growth scenarios}

Policy interventions to change land use are determined through adjustments of the values of various policy variables. In the present study, the environmental conservation policy variables were the subsidy paid to farmers for each unit of converted land (RMB $\mathrm{ha}^{-1}$ ) and the proportion of the total land area (\%) with a slope $>15^{\circ}$. For the scenario analysis, we set the values of these two policy variables as high, moderate, and low in order to examine the resulting land-use changes (Tab. 3). The variables that will affect the land-use changes were defined subjectively according to the projected values of these variables and the plans of the local government. In the conservation policy scenarios, land-use changes and driving factors from the baseline scenarios were used as starting point, and then the effects of the subsidy and area of sloping land were added. The specific values of each policy variable (Tab. 3) used for the simulation were determined as follows: Agenda 21, Ministry of Agriculture, Mini-

Tab. 3 - Key variables used to develop the alternative environmental conservation policy scenarios and resulting land-use changes in Guyuan District from 2010 to 2020. (†): Net present value derived from the subsidy in 2005 , considering the estimated inflation rate (Deng et al. 2008), multiple-cropping index, and governmental investment in land-use conservation in Guyuan District.

\begin{tabular}{|c|c|c|c|c|}
\hline \multirow[b]{2}{*}{ Policy variable } & \multirow[b]{2}{*}{$\begin{array}{c}\text { Projection } \\
\text { year }\end{array}$} & \multicolumn{3}{|c|}{ Environmental conservation scenario } \\
\hline & & $\begin{array}{c}\text { Low } \\
\text { growth }\end{array}$ & $\begin{array}{l}\text { Moderate } \\
\text { growth }\end{array}$ & $\begin{array}{c}\text { High } \\
\text { growth }\end{array}$ \\
\hline Subsidy for converted land & 2010 & 2071.5 & 2589 & 3106.5 \\
\hline$\left(\mathrm{RMB} \mathrm{ha}^{-1}\right) \dagger$ & 2020 & 2619 & 3273 & 3927 \\
\hline Proportion of land area with & 2010 & 0.38 & 0.36 & 0.34 \\
\hline slope $>15^{\circ}(\%)$ & 2020 & 0.26 & 0.24 & 0.23 \\
\hline
\end{tabular}

- Subsidy: Under the moderate growth scenario, we accounted for the estimated inflation rate (Deng et al. 2008), the multiple-cropping index (i.e., the area-weighted proportion of each crop in the study area), and the potential increase in land conservation (OGC 2007), and defined total subsidies of 2589 and $3273 \mathrm{RMB} \mathrm{ha}^{-1}$ in 2010 and 2020 , respectively. The subsidies under the high- and low-growth scenarios were assumed to be $20 \%$ higher and lower, respectively, than the value in the moderate-growth scenario. This percentage was chosen based on local land conversion plans (CDRG 2007).

- Proportion of the land area with a slope $>$ $15^{\circ}$ : We used the value for the base year (2005) for the moderate growth scenario in 2010 , and for 2020 , assumed a total increase of $0.24 \%$ based on the current annual plan for conversion arable land on slopes into grassland and forest (CDRG 2007). The values for the high- and low-growth scenarios were set to $5 \%$ higher and lower, respectively, than the level in the moderate-growth scenario based on local land conversion plans (CDRG 2007).

\section{Modeling framework}

We adopted the DLS modeling framework developed by Deng et al. (2008) to simulate land-use changes in our scenarios. Based on the conversion of land-use and its effects (CLUE) model developed by Verburg et al. (2002), DLS embeds two special features: scenario analysis for land demand under open system (i.e., an initial set of parameter values) and a spatial econometric regression between the explained variables and the explanatory variables. DLS regards the landuse changes occurring under land demand driven by economic and social developments to be an open system with a regional extent. Pixel-specific land-use changes are influenced by various demographic, societal, economic, location, and geophysical factors. We conducted equilibrium analyses of the land supply and demand by sectors and by sub-regions under an open system (Deng et al. 2008), and used the results to simulate the land-use changes at a regional extent.

Given the complexity of land-use systems, the DLS model incorporates parameters accounting for technological changes, lifestyle changes (e.g., food consumption patterns), economic growth (e.g., GDP), population growth, and urbanization. Scenarios for land-use change were developed based on these factors, and the changes in land use were spatially disaggregated into individual cells of the grid based on the simulated relationships between land uses and their influencing factors. There are three main modules in DLS: a spatial regression module that identifies the relationships between land uses and their influencing factors; a scenario anal- 
Tab. 4 - Estimation of the pixel-specific regression model with spatial lag terms for explained variables. Standard errors are included in pa rentheses; the total number of observations was 124 927. Constant terms were estimated but not reported here. ( $\dagger$ ): $W \_y$ represents the spatial lag terms for the explained variables for cultivated land, forest, grassland, water area, built-up area, and unused land.

\begin{tabular}{|c|c|c|c|c|c|c|}
\hline Parameters & $\begin{array}{c}\text { Arable } \\
\text { land }\end{array}$ & Forest & Grassland & $\begin{array}{l}\text { Water } \\
\text { body }\end{array}$ & Built-up & $\begin{array}{c}\text { Unused } \\
\text { land }\end{array}$ \\
\hline$W_{-} y_{\dagger}^{\dagger}$ & $3.039(0.240)$ & $2.142(4.407)$ & $3.136(0.247)$ & $3.649(3.168)$ & $0.075(0.070)$ & $0.001(0.648)$ \\
\hline Cumulative temperature $\left(\geq 0^{\circ} \mathrm{C}-{ }^{\circ} \mathrm{C}\right)$ & $1.000(0.000)$ & $1.000(0.000)$ & $0.999(0.000)$ & $1.000(0.002)$ & $0.999(0.001)$ & $1.000(0.009)$ \\
\hline Cumulative temperature $\left(\geq 10^{\circ} \mathrm{C}-{ }^{\circ} \mathrm{C}\right)$ & $1.000(0.000)$ & $1.000(0.000)$ & $1.001(0.000)$ & $1.002(0.002)$ & $1.000(0.001)$ & $1.000(0.007)$ \\
\hline Average sunshine time (hours) & $1.002(0.000)$ & $1.003(0.001)$ & $0.999(0.000)$ & $0.996(0.003)$ & $1.002(0.002)$ & $0.999(0.025)$ \\
\hline Mean Temperature $\left({ }^{\circ} \mathrm{C}\right)$ & $1.135(0.057)$ & $1.077(0.080)$ & $0.993(0.047)$ & $0.608(0.194)$ & $1.573(0.329)$ & $0.993(0.401)$ \\
\hline Elevation $(\mathrm{m})$ & $1.000(0.000)$ & $1.000(0.000)$ & $1.000(0.000)$ & $0.999(0.000)$ & $1.000(0.000)$ & $1.001(0.007)$ \\
\hline Terrain slope (degrees) & $0.978(0.003)$ & $1.005(0.006)$ & $1.013(0.003)$ & $0.905(0.028)$ & $0.934(0.018)$ & $1.003(0.102)$ \\
\hline Proportion of clay soil (\% by area) & $1.000(0.022)$ & $1.012(0.037)$ & $1.170(0.020)$ & $0.911(0.114)$ & $0.904(0.089)$ & $1.005(0.000)$ \\
\hline Proportion of loam soil ( $\%$ by area) & $1.099(0.013)$ & $1.099(0.022)$ & $0.919(0.012)$ & $1.083(0.088)$ & $0.988(0.056)$ & $0.998(0.780)$ \\
\hline $\begin{array}{l}\text { Mountainous area or not } \\
\text { (=1 if mountainous, }=0 \text { otherwise) }\end{array}$ & $0.322(0.029)$ & $2.943(0.429)$ & $1.000(0.079)$ & $0.325(0.248)$ & $0.525(0.214)$ & $1.211(0.4490$ \\
\hline $\begin{array}{l}\text { Organic matter content in soil } \\
\left(\mathrm{mg} \mathrm{kg}^{-1}\right)\end{array}$ & $1.221(0.075)$ & $1.694(1.362)$ & $1.742(0.578)$ & $1.754(0.376)$ & $1.865(2.791)$ & $0.220(0.760)$ \\
\hline Soil $\mathrm{pH}$ value & $1.236(0.110)$ & $1.021(0.220)$ & $0.930(0.083)$ & $0.428(0.239)$ & $0.584(0.216)$ & $1.002(0.119)$ \\
\hline Phosphorus content in soil $\left(\mathrm{mg} \mathrm{kg}^{-1}\right)$ & $1.001(0.000)$ & $1.376(5.233)$ & $1.079(6.125)$ & $2.860(0.219)$ & $3.480(0.913)$ & $0.996(0.126)$ \\
\hline Potassium content in soil $\left(\mathrm{mg} \mathrm{kg}^{-1}\right)$ & $1.182(0.067)$ & $1.296(1.189)$ & $2.197(0.804)$ & $2.462(0.548)$ & $1.898(2.985)$ & $0.995(0.174)$ \\
\hline Nitrogen content in soil $\left(\mathrm{mg} \mathrm{kg}^{-1}\right)$ & $1.369(0.329)$ & $1.001(0.000)$ & $1.001(0.000)$ & $0.001(0.000)$ & $0.901(0.000)$ & $0.856(0.000)$ \\
\hline Distance to nearest highway $(\mathrm{km})$ & $0.982(0.003)$ & $1.094(0.006)$ & $1.005(0.003)$ & $1.031(0.022)$ & $0.991(0.016)$ & $1.235(0.137)$ \\
\hline $\begin{array}{l}\text { Distance to provincial/secondary } \\
\operatorname{road}(\mathrm{km})\end{array}$ & $0.992(0.002)$ & $1.090(0.004)$ & $1.007(0.002)$ & $0.996(0.014)$ & $0.967(0.009)$ & $1.112(0.153)$ \\
\hline Distance to provincial capital $(\mathrm{km})$ & $0.993(0.001)$ & & & & & \\
\hline Distance to county/tertiary road $(\mathrm{km})$ & $1.012(0.006)$ & $1.085(0.014)$ & $1.987(0.006)$ & $0.962(0.036)$ & $0.983(0.028)$ & $1.672(0.252)$ \\
\hline Population density (persons $\mathrm{m}^{-2}$ ) & $1.000(0.000)$ & $0.996(0.001)$ & $0.997(0.000)$ & $1.000(0.001)$ & $1.000(0.001)$ & $1.000(0.004)$ \\
\hline GDP density $(\times 10000$ RMB $)$ & $1.009(0.002)$ & $1.021(0.006)$ & $0.994(0.003)$ & $1.007(0.009)$ & $1.032(0.005)$ & $0.965(0.045)$ \\
\hline Average income (RMB) per capita & $1.000(0.000)$ & $1.000(0.00$ & $1.000(0.000)$ & $1.001(0.001)$ & $1.001(0.000)$ & $0.999(0.003)$ \\
\hline Number of township hospitals & $1.029(0.024)$ & $0.979(0.049)$ & $1.094(0.029)$ & $1.069(0.137)$ & $1.021(0.081)$ & $0.963(1.005)$ \\
\hline Number of students per township & $1.000(0.000)$ & $1.000(0.000)$ & $1.000(0.000)$ & $1.000(0.000)$ & $1.000(0.000)$ & $1.000(0.000)$ \\
\hline$R^{2}$ & 0.503 & 0.556 & 0.483 & 0.428 & 0.412 & 0.449 \\
\hline
\end{tabular}

ysis module that identifies the land-use changes required by the regional demand for each land use; and a spatial disaggregation module that allocates the overall regional land-use changes to the disaggregated grid cells.

\section{Population projections and the grain-} balance analysis

We predicted the future population of Guyuan District to let us compare the grain supply (based on the predicted land-use changes) with the grain demand (based on the predicted population changes) in 2005 , 2010 , and 2020. We used the following equation for the population projection (eqn. $1)$ :

$$
P=P_{0}-A e^{-y}
$$

where $P$ is the total population in the projection year, $P_{0}$ is the population in the initial year of the simulation (2005), $y$ represents the exact year number for simulation (i.e., the number of years between the initial year and the projection year), and $A$ is the annual population growth rate. In this study, we defined population growth rates of $0.58,0.40$, and $0.17 \%$ for the high-, moderate-, and low-growth scenarios.
We calculated grain equivalents based on the total grain production and the total grain demand of a given population level. Grains included winter wheat, spring-sown maize, millet, buckwheat, and potatoes. Other crops which did not account for a significant proportion of the total harvest were omitted.

\section{Results}

\section{Analysis of driving factors for the}

dynamics of land-use change

Tab. 4 summarizes the regression coefficients for the factors influencing the land uses of arable land, forest, grassland, water area, built-up areas, and unused land in Guyuan District in 2005. The standard errors in parentheses indicate that the influencing factors vary in their effect on the land use dynamics. The smaller the standard error, the stronger the parameter's effect on the landuse dynamics. For instance, the cumulative temperatures above 0 and $10{ }^{\circ} \mathrm{C}$, elevation, population density, and per capita income strongly affect the change in the areas of arable land, forest, and grassland, and the sunshine duration and phosphorus concentration in the soil strongly affect the area of arable land.

\section{Dynamic simulation of land-use changes}

Among the six land-use categories defined by the Chinese Academy of Sciences (Liu et al. 2002), the dominant land uses of Guyuan in 2005 were grassland $(46.8 \%)$ and arable land $(43.2 \%)$, followed by forest $(7.4 \%)$, built-up land $(1.7 \%)$, and bodies of water and other unused land $(<1 \%)$. Unused land is land which cannot be used directly, including saline-alkali soil land, marshland, sandy soil land, and bare exposed rock or gravel (Fig. 2).

Results from the scenario analysis show that the balance among the major land-use types in Guyuan District did not change greatly under any of the scenarios, with arable land and grassland remaining the dominant land uses (accounting for more than $80 \%$ of the total land area), followed by forest, built-up land, bodies of water, and unused land (Tab. 5). In comparison with the baseline scenario, clear differences in the trends for the high-, moderate-, and lowgrowth scenarios were obtained (Tab. 5, Fig. 3 and Fig. 4).

Changes in land use under the influence of the conservation policy scenarios were characterized by a steady decrease in the area of arable land, with the proportion of the total 
Fig. 2 - Spatial distribution of the main land uses in 2005 , based on supervised classification of Landsat TM data.

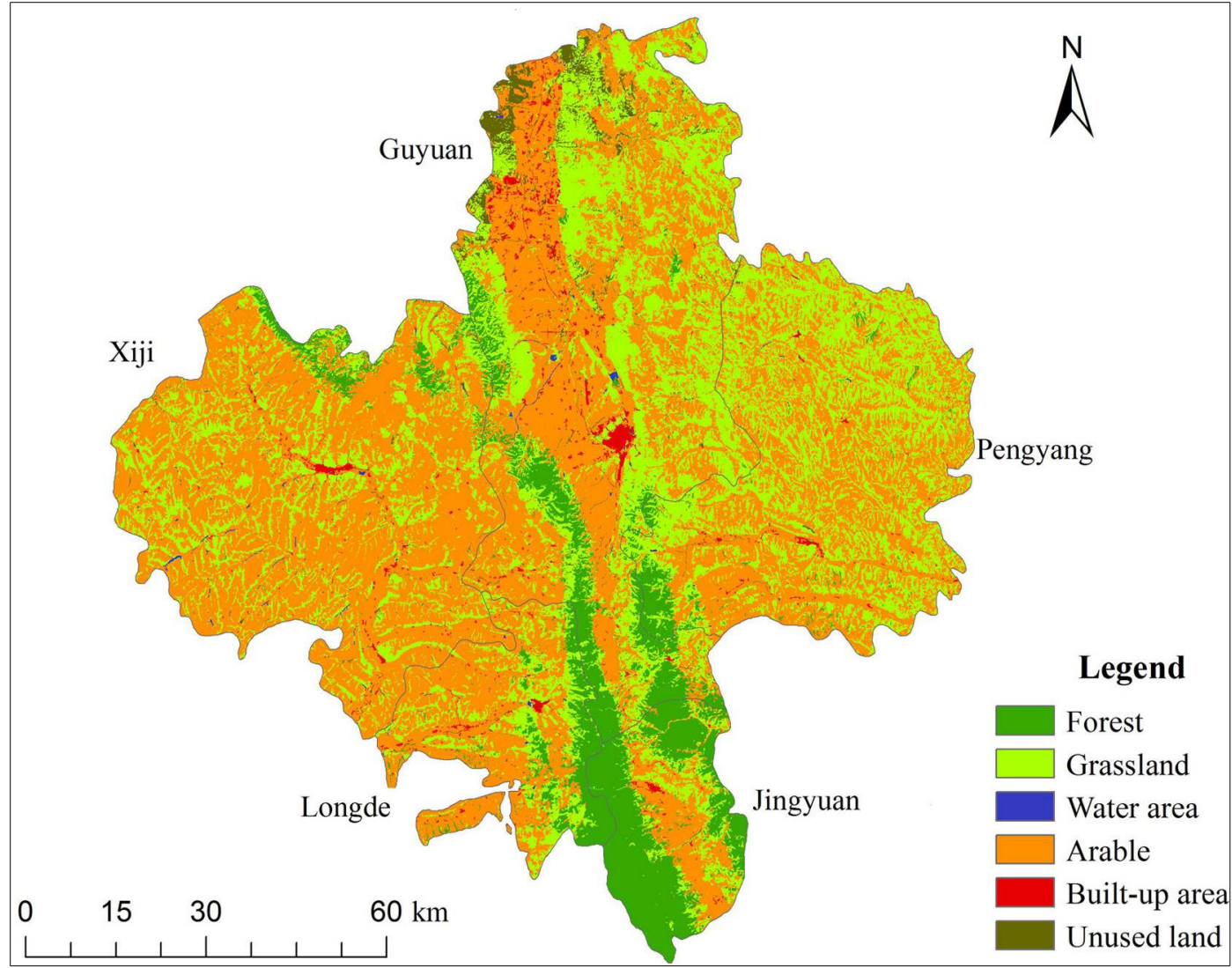

Tab. 5 - Land-use changes (in terms of area $\times 10^{3}$ ha) under the three baseline scenarios and the three environmental conservation scenarios from 2005 to 2020 . Unused land is not listed due to its small and relatively stable land area (ca. 100 ha) in all scenarios. ( $\dagger$ ): Numbers in parentheses represent the increase $(+)$ and decrease $(-)$ in the area or percentage of each of land-use category compared with the value in the base year. $(\$)$ : Percentages of the total land area.

\begin{tabular}{|c|c|c|c|c|c|c|c|c|c|c|c|c|}
\hline \multirow{2}{*}{ Type } & \multirow{2}{*}{ Scenario } & \multirow{2}{*}{ Year } & \multicolumn{2}{|c|}{ Arable land } & \multicolumn{2}{|c|}{ Grassland } & \multicolumn{2}{|c|}{ Forest } & \multicolumn{2}{|c|}{ Built-up land } & \multicolumn{2}{|c|}{ Water body } \\
\hline & & & Area & $\%$ & Area & $\%$ & Area & $\%$ & Area & $\%$ & Area & $\%$ \\
\hline \multirow[t]{2}{*}{ none } & Base year & 2005 & 66.9 & 46.4 & 64.2 & 44.5 & 9.9 & 6.8 & 2.3 & 1.6 & 1.0 & 0.7 \\
\hline & & & $(0.0)$ & $(0.0)$ & $(0.0)$ & $(0.0)$ & $(0.0)$ & $(0.0)$ & $(0.0)$ & $(0.0)$ & $(0.0)$ & $(0.0)$ \\
\hline \multirow{11}{*}{$\begin{array}{l}\text { Baseline } \\
\text { scenarios }\end{array}$} & Low & 2010 & 65.9 & 45.7 & 63.3 & 43.9 & 10.6 & 7.2 & 3.2 & 2.2 & 1.1 & 0.8 \\
\hline & growth & & $(-1.0)$ & $(-0.7)$ & $(-0.9)$ & $(-0.6)$ & $(0.7)$ & $(0.4)$ & $(0.9)$ & $(0.6)$ & $(0.1)$ & $(0.1)$ \\
\hline & & 2020 & $\begin{array}{c}65.2 \\
(-1.7)\end{array}$ & $\begin{array}{l}45.2 \\
(-1.2)\end{array}$ & $\begin{array}{c}62.6 \\
(-1.6)\end{array}$ & $\begin{array}{c}43.4 \\
(-1.1)\end{array}$ & $\begin{array}{l}11.1 \\
(1.2)\end{array}$ & $\begin{array}{l}7.7 \\
(0.9)\end{array}$ & $\begin{array}{c}4.1 \\
(1.8)\end{array}$ & $\begin{array}{c}2.9 \\
(1.3)\end{array}$ & $\begin{array}{l}1.2 \\
(0.2)\end{array}$ & $\begin{array}{c}0.8 \\
(0.1)\end{array}$ \\
\hline & Moderate & 2010 & 65.5 & 45.4 & 63.1 & 43.7 & 11.1 & 7.7 & 3.4 & 2.4 & 1.1 & 0.8 \\
\hline & growth & & $(-1.4)$ & $(-1.0)$ & $(-1.1)$ & $(-0.8)$ & $(1.2)$ & $(0.9)$ & (1.1) & $(0.8)$ & $(0.1)$ & $(0.1)$ \\
\hline & & 2020 & 64.3 & 44.6 & 62.0 & 43.0 & 12.1 & 8.4 & 4.6 & 3.2 & 1.2 & 0.8 \\
\hline & & & $(-2.6)$ & $(-1.8)$ & $(-2.2)$ & $(-1.5)$ & $(2.2)$ & (1.6) & (1.3) & (1.6) & $(0.2)$ & $(0.1)$ \\
\hline & High & 2010 & 64.6 & 44.8 & 62.5 & 43.3 & 12.2 & 8.5 & 3.6 & 2.5 & 1.2 & 0.8 \\
\hline & growth & & $(-2.3)$ & $(-1.6)$ & $(-1.7)$ & $(-1.2)$ & (2.3) & (1.7) & (1.3) & $(0.9)$ & $(0.2)$ & $(0.1)$ \\
\hline & & 2020 & 62.6 & 43.4 & 60.9 & 42.2 & 14.4 & 9.9 & 4.9 & 3.4 & 1.4 & 1.0 \\
\hline & & & $(-4.3)$ & $(-3.0)$ & $(-3.3)$ & $(-2.3)$ & $(4.5)$ & (3.1) & (2.6) & $(1.8)$ & $(0.4)$ & $(0.3)$ \\
\hline \multirow{12}{*}{$\begin{array}{l}\text { Environmental } \\
\text { conservation } \\
\text { scenarios }\end{array}$} & Low & 2010 & 62.5 & 43.3 & 63.8 & 44.2 & 13.5 & 9.3 & 3.4 & 2.3 & 1.1 & 0.8 \\
\hline & growth & & $(-4.4)$ & $(-3.1)$ & $(-0.4)$ & $(-0.3)$ & (3.6) & (2.5) & (1.1) & $(0.7)$ & $(0.1)$ & $(0.1)$ \\
\hline & & 2020 & 58.3 & 40.4 & 63.4 & 44.0 & 16.9 & 11.7 & 4.4 & 3.1 & 1.2 & 0.8 \\
\hline & & & $(-8.6)$ & $(-6.0)$ & $(-0.8)$ & $(-0.5)$ & $(7.0)$ & (4.9) & $(2.1)$ & (1.5) & $(0.2)$ & $(0.1)$ \\
\hline & Moderate & 2010 & 61.8 & 42.8 & 63.8 & 44.2 & 14.3 & 9.9 & 3.2 & 2.2 & 1.1 & 0.8 \\
\hline & growth & & $(-5.1)$ & $(-3.6)$ & $(-0.4)$ & $(-0.3)$ & (4.5) & (3.1) & $(0.9)$ & $(0.6)$ & $(0.1)$ & $(0.1)$ \\
\hline & & 2020 & 56.9 & 39.5 & 63.4 & 44.0 & 18.6 & 12.9 & 4.0 & 2.8 & 1.2 & 0.8 \\
\hline & & & $(-9.9)$ & $(-6.9)$ & $(-0.7)$ & $(-0.5)$ & (8.7) & (6.1) & (1.8) & $(1.2)$ & $(0.2)$ & $(0.1)$ \\
\hline & High & 2010 & 60.9 & 42.2 & 64.3 & 44.6 & 15.0 & 10.4 & 3.0 & 2.1 & 1.1 & 0.8 \\
\hline & & & $(-6.0)$ & $(-4.2)$ & $(0.1)$ & $(0.1)$ & (5.1) & (3.6) & $(0.7)$ & $(0.5)$ & $(0.1)$ & (0.1) \\
\hline & & 2020 & 55.1 & 38.2 & 64.5 & 44.7 & 19.8 & 13.7 & 3.6 & 2.5 & 1.2 & 0.8 \\
\hline & & & $(-11.8)$ & $(-8.2)$ & $(0.3)$ & $(0.2)$ & $(10.0)$ & (6.9) & (1.4) & $(0.9)$ & $(0.2)$ & $(0.1)$ \\
\hline
\end{tabular}




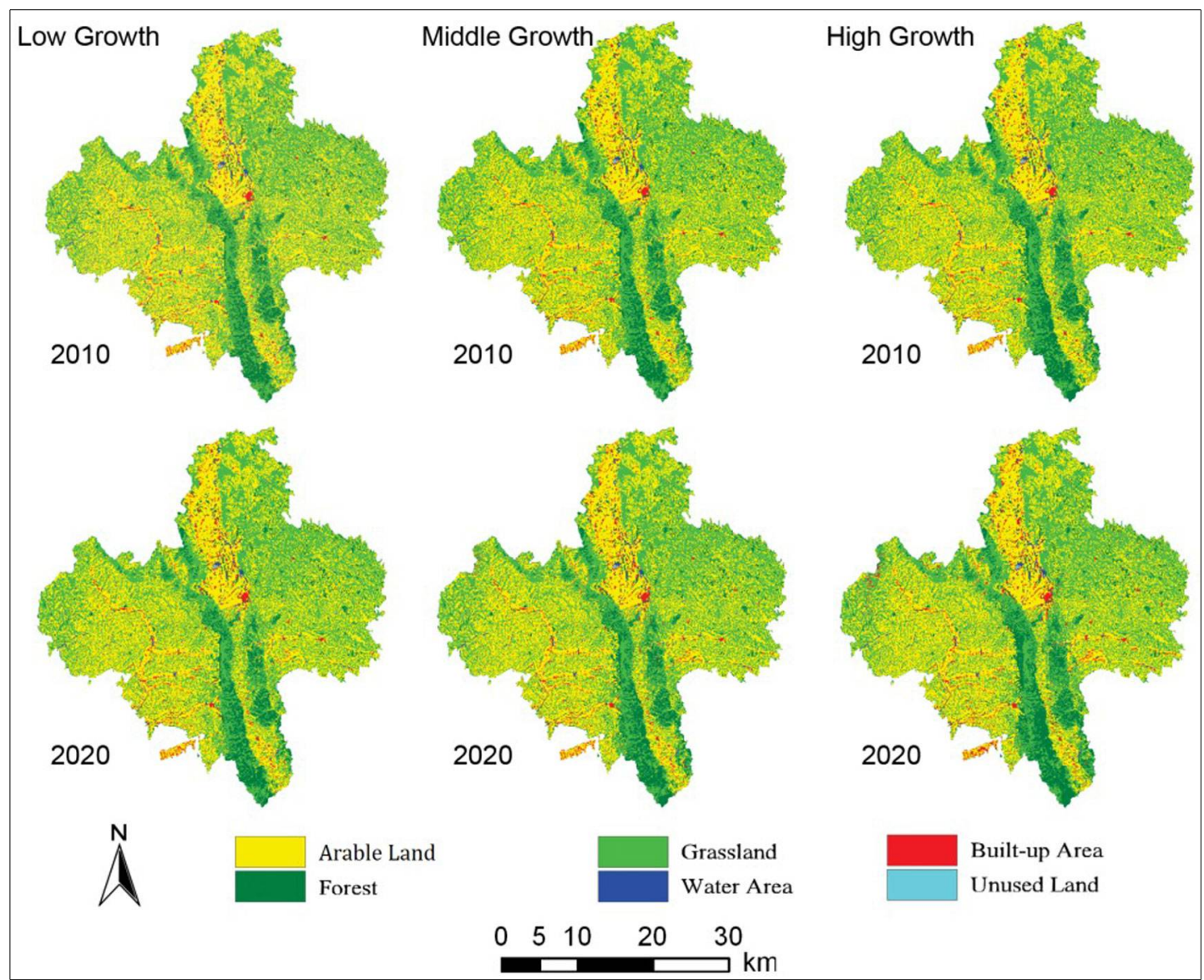

Fig. 3 - Simulated landuse pattern in Guyuan District under the baseline scenarios.
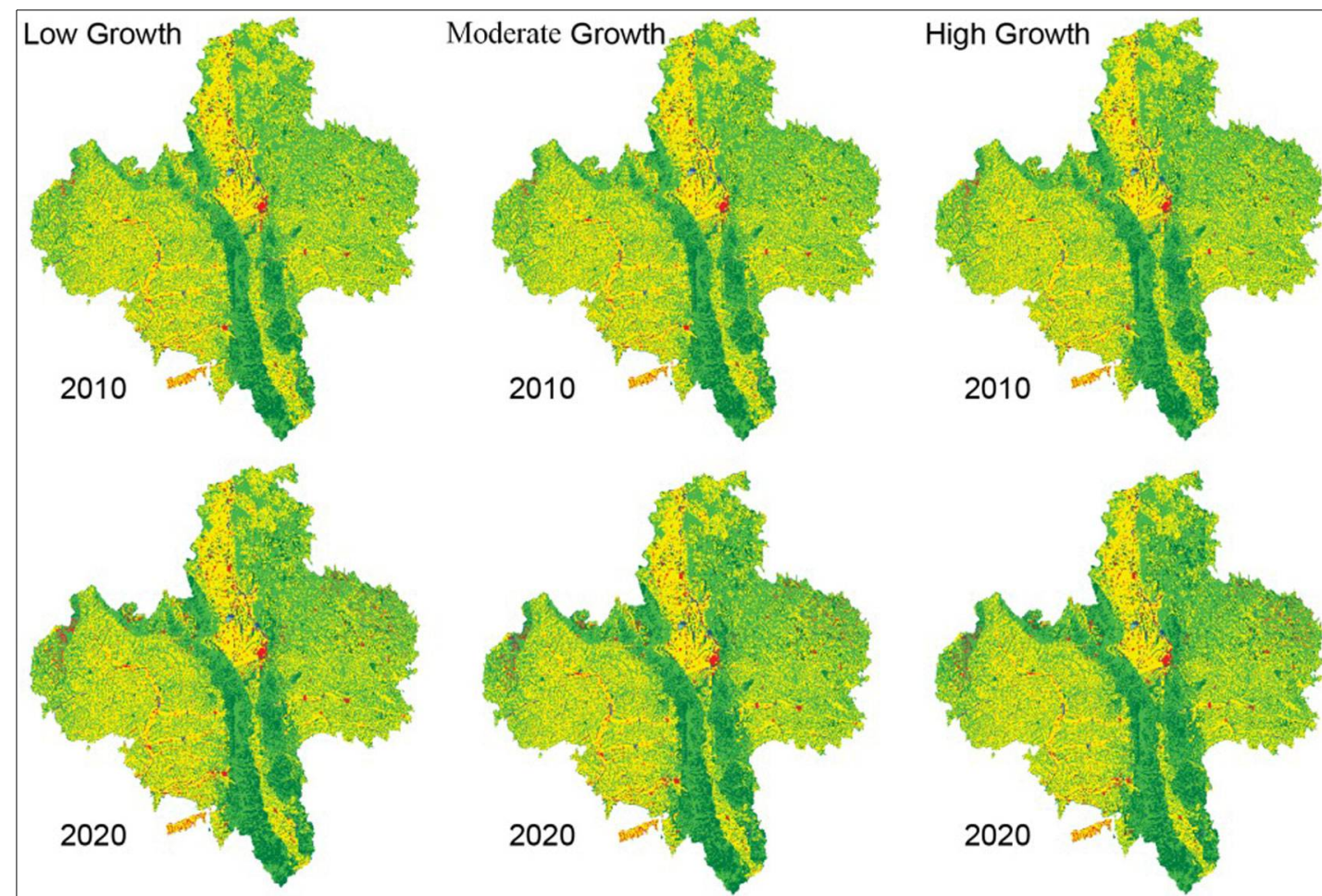

Fig. 4 - Simulated landuse pattern in Guyuan District under the environmental conservation scenarios.
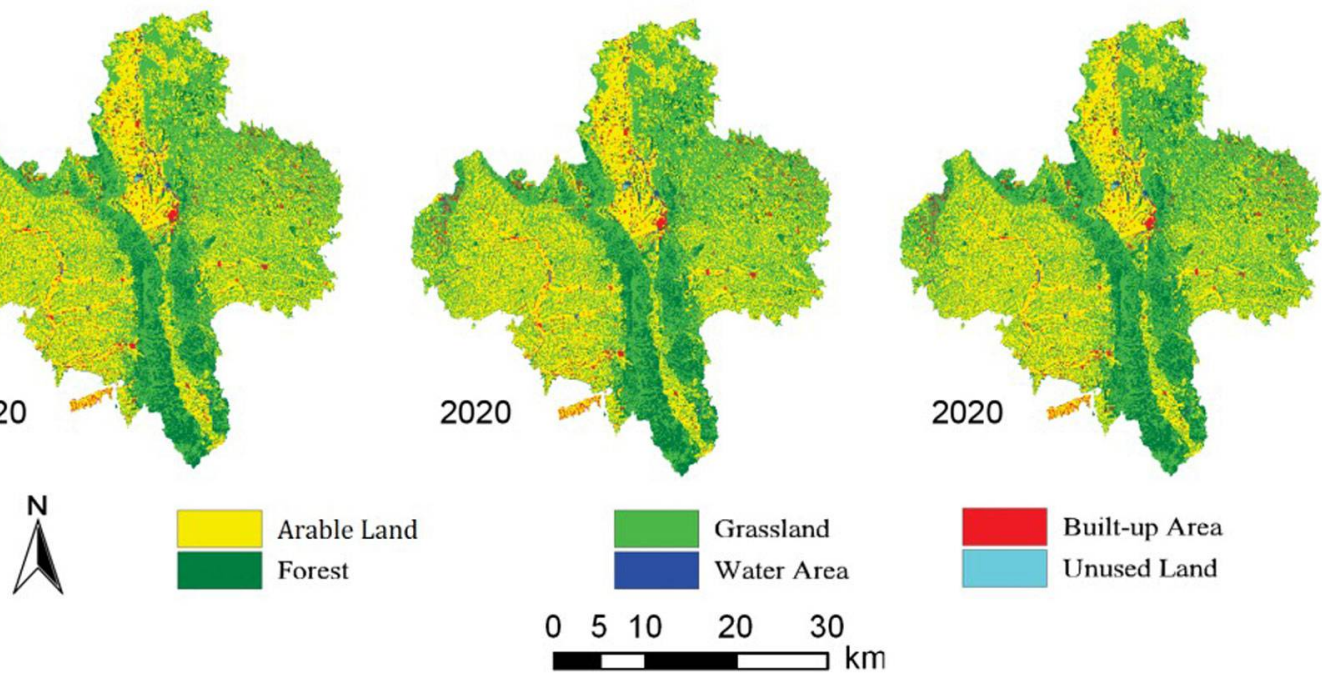

$\mathrm{km}$ 
Fig. 5 - Land use transitions in Guyuan under baseline and environmental conservation scenarios.

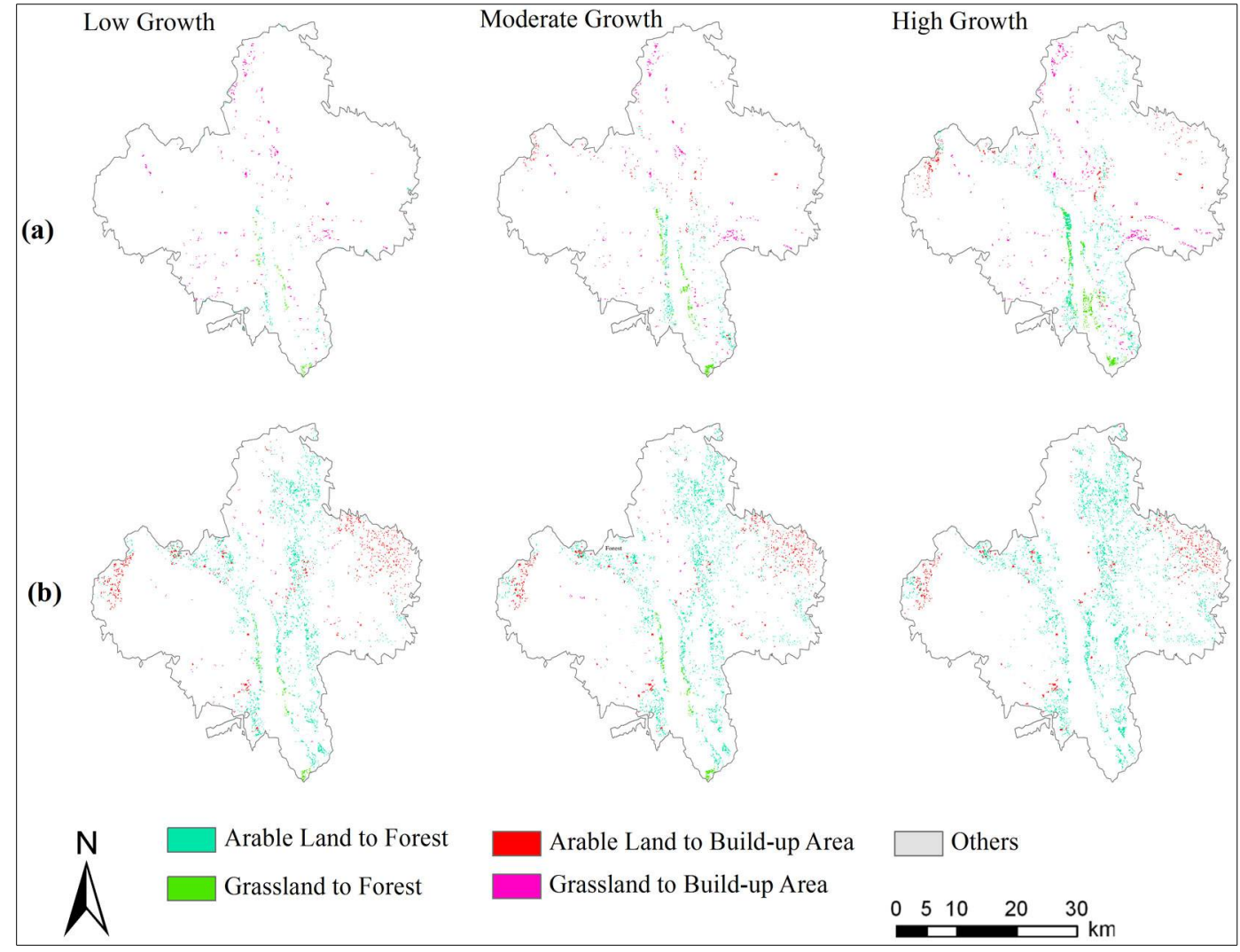

area accounted for by arable land in 2010 decreasing (as compared with the value in the base year) by 3.1, 3.6, and $4.2 \%$ in the low-, moderate-, and high-growth scenarios, respectively; the corresponding decreases by 2020 were $6.0,6.9$, and $8.2 \%$, respectively. About half of the decrease in the area of arable land is expected to originate from an increase in built-up areas, whereas other losses will occur as a result of conversion to horticultural uses (e.g., parks and gardens), and rehabilitation of land through reforestation or grassland restoration (Fig. 5 - Feng et al. 2005, Verburg et al. 2000, Yang 2006). The decrease in the area of arable land is clearly greatest in the high-growth scenario. The relatively high subsidy for the conversion of arable land into grassland and forest, as well as restrictions on crop cultivation on slopes $>15^{\circ}$, will decrease the area of arable land compared with the baseline scenario. Most of the converted arable land is distributed near built-up land and sloping land (Fig. 24). Compared with the baseline scenario, the decrease in arable land is greater under the conservation policy scenarios. For example, in the high-growth scenario, $4.2 \%$ (2010) and $8.2 \%$ (2020) of the area of arable land will be lost under the environmental conservation policy, versus 1.6 and $3.0 \%$, respectively, under the baseline scenario.

The area of grassland decreased at the same rates in the low- and moderate-growth conservation scenarios in $2010(0.3 \%)$ and 2020
$(0.5 \%)$, and increased in the high-growth scenario, with a slightly higher rate in 2020 $(0.2 \%)$ than in $2010(0.1 \%)$. This suggests that the increase in grassland strongly depends on government incentives (high subsidy) and regulations (which mandate the conversion of farmland on steep slopes into grassland and forest). Existing large areas of grassland also slow the rate of further expansion. Decreases in the area of grassland resulted mainly from its conversion into arable land and forest, whereas increases resulted from conversion of forest and arable land into grassland (Yang 2006, Zhen et al. 2007). However, in the baseline scenario, the area of grassland continues to decrease under all three growth rates.

Forest and built-up areas showed a steady expansion. The area of forest increased by $2.5,3.1$, and $3.6 \%$ by 2010 under the low-, moderate-, and high-growth scenarios, respectively, with corresponding values of 4.9, 6.1 , and $6.9 \%$ in 2020. Built-up areas increased by $0.7,0.6$, and $0.5 \%$ in 2010 in the low-, moderate-, and high-growth scenarios, respectively, higher than national average of $0.25 \%$ from $2002-2008$, due to the fact that the initial value of built-up areas was relatively smaller in less developed western China like Guyuan than rest of the country; therefore, the net area increase would be higher compared to the country average (Wang et al. 2012). The built-up areas will increase by $1.5,1.2$, and $0.9 \%$ under respective scena- rios by 2020 . The area of forest expanded mostly in the central mountains of Guyuan District, and resulted primarily from the conversion of nearby grassland (Fig. 3 and Fig. 4 - Zhen et al. 2007). The continuous increase in the area of forest resulted from the governmental policy, in that the benefits to be obtained from forested land (e.g., forest products) created from arable land will be owned by the farmers (State Council 1998). This expansion of forest is higher in the conservation policy scenarios than in the baseline scenarios (Tab. 5).

Urban and rural settlements and other built-up areas would expand dramatically under the baseline scenario, and the newly expanded urban land would mainly appear near existing urban areas or residential centers. This increase would be the fastest in the low-growth scenario, followed by the moderate- and high-growth scenarios, in both 2010 and 2020. This would result from the strong enforcement of the policy to increase forest and grassland areas. Even so, no largescale, interconnected urban areas will develop in Guyuan District by the end of 2020 , and the increase in the built-up area under the conservation policy will be less than that under the baseline scenario (Tab. 5).

The change in the area of bodies of water in Guyuan District, which is affected by annual variations in precipitation, would be relatively small compared with the changes in other land uses (i.e., $0.8 \%$ of total land 
Tab. 6 - Grain production and demand in Guyuan District from 2005 to 2020 under the baseline (BL) and conservation policy (CP) scenarios. Numbers in parentheses represent the percentage increase (+) or decrease (-) in comparison with the base year (2005).

\begin{tabular}{|c|c|c|c|c|c|c|c|c|}
\hline Year & Scenario & & $\begin{array}{l}\text { Cultivated } \\
\text { area } \\
\left(\times 10^{3} \mathrm{ha}\right)\end{array}$ & $\begin{array}{c}\text { Total } \\
\text { production } \\
\left(\times 10^{3} \text { t grain }\right)\end{array}$ & $\begin{array}{c}\text { Total } \\
\text { population } \\
\left(\times 10^{3}\right)\end{array}$ & $\begin{array}{l}\text { Per capita } \\
\text { grain } \\
\text { production } \\
(\mathrm{kg} / \mathrm{yr})\end{array}$ & $\begin{array}{l}\text { Grain } \\
\text { demand } \\
\left(\times 10^{3} t\right)\end{array}$ & $\begin{array}{c}\text { Grain } \\
\text { balance } \\
\left(\times 10^{3} t\right)\end{array}$ \\
\hline 2005 & Base year & & $369.3(0.0)$ & $538.0(0.0)$ & $1556.2(0.0)$ & 346 & $315.3(0.0)$ & 222.7 \\
\hline \multirow[t]{6}{*}{2010} & Low growth & $\mathrm{BL}$ & $381.2(+3.2)$ & $558.3(+3.8)$ & $1575.9(+1.3)$ & 354 & $355.8(+12.8)$ & 202.5 \\
\hline & & $\mathrm{CP}$ & $367.4(-0.5)$ & $538.1(+0.1)$ & & 341 & & 182.2 \\
\hline & Moderate growth & $\mathrm{BL}$ & $381.8(+3.4)$ & $559.2(+3.9)$ & $1589.5(+2.1)$ & 352 & $358.8(+13.8)$ & 200.4 \\
\hline & & $\mathrm{CP}$ & $365.6(-1.0)$ & $535.4(-0.5)$ & & 337 & & 176.6 \\
\hline & High growth & $\mathrm{BL}$ & $382.4(+3.5)$ & $560.1(+4.1)$ & $1603.1(+3.0)$ & 349 & $361.9(+14.8)$ & 198.2 \\
\hline & & $\mathrm{CP}$ & $363.7(-1.5)$ & $532.7(-1.0)$ & & 332 & & 170.8 \\
\hline \multirow[t]{6}{*}{2020} & Low growth & $\mathrm{BL}$ & $382.5(+3.6)$ & $599.2(+11.4)$ & $1605.9(+3.2)$ & 373 & $637.1(+102.1)$ & -37.9 \\
\hline & & $\mathrm{CP}$ & $363.8(-1.5)$ & $569.9(+5.9)$ & & 355 & & -67.2 \\
\hline & Moderate growth & $\mathrm{BL}$ & $385.2(+4.3)$ & $603.6(+12.2)$ & $1650.4(+6.1)$ & 366 & $654.8(+107.7)$ & -51.22 \\
\hline & & $\mathrm{CP}$ & $358.3(-3.0)$ & $561.4(+4.3)$ & & 340 & & -93.4 \\
\hline & High growth & $\mathrm{BL}$ & $387.7(+5.0)$ & $607.4(+12.9)$ & $1696.1(+9.0)$ & 358 & $672.9(+113.4)$ & -65.5 \\
\hline & & $\mathrm{CP}$ & $352.9(-4.4)$ & $553.1(+2.8)$ & & 326 & & -119.9 \\
\hline
\end{tabular}

use). Therefore, the area and spatial distribution of bodies of water would remain largely unchanged during the simulation period in both the baseline and conservation policy scenarios. Unused land accounts for a very small proportion of the total land area $(0.04 \%)$, and its area will increase slightly (e.g., to about $0.10 \%$ in all scenarios) or will remain unchanged. Biophysical constraints such as low precipitation will limit changes in water bodies, and the poor quality of the soils in unused land (which has undergone severe soil erosion, or which has a high abundance of rocks and stones) limit the potential other uses of this land.

Impacts of land-use changes on grain production and food security

We analyzed changes in food security based on projections of regional agricultural production and population growth. Based on the land-use changes under the baseline and conservation policy scenarios, we estimated grain balances (surpluses or deficits). Tab. 6 summarizes the scenario for the area cultivated, the total supply (production) and demand for grains, and the resulting net grain balance. Compared with the base year (2005), the arable area in the baseline scenario increased by $3.2,3.4$, and $3.5 \%$ in 2010 under the low-, moderate-, and high-growth scenarios, respectively, versus corresponding increases of 3.6, 4.3, and $5.0 \%$ in 2020. Therefore, if current land-use drivers continue to act at the predicted levels in the future, the arable area will continue to increase. However, the arable area in the conservation policy scenario in 2010 will decrease by 0.5 ,

Tab. 7 - Land demands for the production of major crops by local farmers. ( $\dagger$ ): Percentage decrease of land area from 2005 to 2020.

\begin{tabular}{|c|c|c|c|c|c|c|}
\hline \multirow[b]{2}{*}{ Policy Scenarios } & \multirow[b]{2}{*}{ Crops } & \multicolumn{5}{|c|}{ Area (ha) } \\
\hline & & 2005 & 2010 & 2015 & 2020 & $\begin{array}{c}\text { Change } \\
(\%) \dagger\end{array}$ \\
\hline \multirow{6}{*}{$\begin{array}{l}\text { Low-growth } \\
\text { scenario }\end{array}$} & Grain & 33323.1 & 33234.0 & 33144.8 & 33055.7 & -0.8 \\
\hline & Wheat & 19857.7 & 19804.5 & 19751.4 & 19698.3 & -0.8 \\
\hline & Maize & 4478.3 & 4466.3 & 4454.3 & 4442.3 & -0.8 \\
\hline & Tubers & 14425.3 & 14386.7 & 14348.2 & 14309.6 & -0.8 \\
\hline & Beans & 6462.9 & 6445.6 & 6428.3 & 6411.0 & -0.8 \\
\hline & Oil plants & 7825.0 & 7804.1 & 7783.1 & 7762.2 & -0.8 \\
\hline \multirow{6}{*}{$\begin{array}{l}\text { Moderate-growth } \\
\text { scenario }\end{array}$} & Grain & 33236.3 & 33060.3 & 32884.4 & 32708.5 & -1.6 \\
\hline & Wheat & 19805.9 & 19701.1 & 19596.3 & 19491.4 & -1.6 \\
\hline & Maize & 4466.6 & 4443.0 & 4419.3 & 4395.7 & -1.6 \\
\hline & Tubers & 14387.8 & 14311.6 & 14235.4 & 14159.3 & -1.6 \\
\hline & Beans & 6446.0 & 6411.9 & 6377.8 & 6343.7 & -1.6 \\
\hline & Oil plants & 7804.6 & 7763.3 & 7722.0 & 7680.7 & -1.6 \\
\hline \multirow{6}{*}{$\begin{array}{l}\text { High-growth } \\
\text { scenario }\end{array}$} & Grain & 33062.7 & 32713.1 & 32363.6 & 32014.1 & -3.3 \\
\hline & Wheat & 19702.5 & 19494.2 & 19285.9 & 19077.6 & -3.3 \\
\hline & Maize & 4443.3 & 4396.3 & 4349.3 & 4302.4 & -3.3 \\
\hline & Tubers & 14312.6 & 14161.3 & 14010.0 & 13858.7 & -3.3 \\
\hline & Beans & 6412.4 & 6344.6 & 6276.8 & 6209.0 & -3.3 \\
\hline & Oil plants & 7763.8 & 7681.8 & 7599.7 & 7517.6 & -3.3 \\
\hline
\end{tabular}

1.0 , and $1.5 \%$ under the low-, moderate-, and high-growth scenarios, respectively, versus corresponding decreases of $1.5,3.0$, and $4.4 \%$ by 2020 . The decrease in the arable area under the conservation policy scenario will result from continued implementation of the SLCP.

Grain demand will continue to increase between 2005 and 2020, primarily because of population growth, but also because of our assumption that consumption will increase as prosperity increases due to economic growth. The grain balance, which represents the gap between total production and total demand, will decrease continuously until 2020 in all scenarios and for all rates of growth. There will be a surplus of grain in all scenarios in 2010 , but the surplus will be lower under the conservation policy scenarios. By 2020, the grain balance will become negative in all scenarios (i.e., a deficit), indicating that regional grain production can no longer meet the increasing demand from the region's population. However, the deficit will increase with increasing growth rate, and will be larger under the conservation policy scenarios than in the baseline scenarios. Therefore, implementation of the environmental conservation policy, coupled with a decrease in the area of arable land, population growth, and increasing prosperity, will lead to food shortages that must be met by imports from other regions. The impacts of improved cultivation technology on the grain yields has been identified and represented in scenario analyses based on historical trends and predicted future technological development (CDRG 2007).

Total grain production decreased in the conservation policy scenarios compared to the baseline scenarios. For example, in 2010, the decrease was $3.7,4.4$, and $5.1 \%$, respectively, in the low-, moderate-, and highgrowth scenarios, versus corresponding va- 
lues of 5.5, 7.9 and $10.1 \%$, respectively, in 2020 , suggesting a greater decrease in production in the high-growth scenario. Therefore, the decrease in the area of arable land under the conservation policy scenario will reduce the area available for grain production and increase the risk of grain shortages compared with the baseline scenario. For example, in the simulation year of 2010 , the total grain loss in the high-growth conservation scenario, in comparison with the lowgrowth scenario, is $5400 \mathrm{t}$ (with a loss of arable land of 1.5 and $0.5 \%$ respectively in comparison with the base year); in 2020, the total grain loss increases to $16800 \mathrm{t}$ in the high-growth conservation scenario compared to the low-growth scenario, with the percentage decrease in the area of arable land of 4.4 and $1.5 \%$, respectively (Tab. 6). We calculated the land area required to meet the demand for each crop based on the predicted productivity per unit area for that crop (Tab. 7). Minor shifts in land use can be seen for each major crop. The land area of the major crops decreased by $0.8,1.6$, and $3.3 \%$, respectively, in the low-, moderate-, and highgrowth conservation scenarios, which sug gests that the decreased area of arable land will affect each of the major crops under cultivation.

\section{Discussion}

\section{Land-use dynamics}

Between 40 and $90 \%$ of the decrease in the area of arable land in Guyuan District is estimated to have resulted from the SLCP (Chen 2008). However, the history of landuse change in Guyuan District shows that the area of arable land increased by $8.3 \%$ (39 111 ha) from 1986 to 2000 , and $97.9 \%$ of the new arable land was converted from grassland and the rest was converted from former bodies of water (mostly where the water had dried up or was drained) or fores (Chen 2008, Zhang et al. 2006). This increase mainly resulted from the high proportion of total GDP accounted for by agriculture (more than $50 \%$ ), the high proportion of the rural population (more than $85 \%$ ), and low agricultural productivity during this period (Chen 2008). The high reliance of the local economy on agricultural production motivated farmers to reallocate land from grassland and forest to farmland to improve the grain supply. Our study revealed that, although the arable land area is decreasing, only minor decreases in the area of agricultural land are expected based on simulations (Tab. 7). There are two main reasons for this: the regulations for basic farmland protection place tight restrictions on land conversions from protected agricultural land to non-agricultural uses; and, because the study area is located in a dry and remote mountainous region, all of the farmer households rely heavily on farming for their livelihood, so they protect their agricultural land carefully. The production of this land is maintained by means of high inputs (e.g., fertilizer) rather than by expansion of the arable area.

Though differences between the analyzed scenarios seem minor, they are significant enough to provide guidance for policy development. We found that the difference in the area of arable land between the high- and low-growth environmental protection scenarios would be nearly $1.1 \times 10^{4}$ ha in 2020 , which accounts for more than $3.0 \%$ of the total arable area in Guyuan District. The Chinese government has defined $1.2 \times 10^{8}$ ha as the minimum area (the "red warning line") for arable land in China to ensure food self-sufficiency. The implication of this standard for each of China's districts and counties is that the area of arable land reserved for grain cultivation must be strictly protected.

\section{Grain balance}

Grain yield in Guyuan District has increased at an annual rate of $9 \%$ from 1971 to 2005 , mainly based on improvements in production technology and increased production inputs (Chen 2008). As a result, the district has maintained self-sufficiency in food production for the past 30 years. Since the current land-use conversion process is expected to last for an additional 10 to 30 years (Feng et al. 2005), the impacts on the total grain balance should generally be small, but they will nonetheless be significant at the local level. For example, our simulations revealed a severe grain deficiency by the end of the simulation period (2020) under both the baseline and the conservation policy scenarios. Some authors have concluded that the ongoing conversion of arable areas into other uses under the SLCP will significantly reduce total production (Feng \& Li 2000, Tan \& Peng 2003), but that agricultural productivity will increase in north-central China as a result of more intensive agricultural practices and the development of improved cultivation technology for the remaining land (Feng et al. 2005). However, our study considers the predicted average grain yield in the scenario analysis, and the result shows that even though grain yield (including winter wheat, spring-sown maize, millet, buckwheat, and potatoes) is increasing, the grain demand is increasing as a result of population growth and grain production is simultaneously being undermined by the loss of farmland for ecological conservation. Accordingly, the grain losses in our simulations lead to serious concerns about regional food security and may lead to a need to import food from outside the Guyuan District.

Land-use change and its impact on food production have been studied previously. For instance, Belsky \& Siebert (2003) ob- served results similar to ours in Indonesia, and concluded that the conversion of swidden fields into cacao plantations, which produce a cash crop that is vulnerable to global market trends, constrains future food production opportunities and raises significant concerns over local food security and agricultural sustainability. Case studies on land conversion and food security in western China have produced a range of conclusions. For example, Feng et al. (2002) found that if land conversion continues as planned, a total of $400 \times 10^{4} \mathrm{t}$ of grains will be lost, but that this will not have negative impacts on food security because production by the remaining farmland can be enhanced by increased agricultural inputs. In addition, the improvement of ecological conditions brought about by the increased forest and grassland areas will decrease the frequency of natural disasters and help to secure grain yields, despite reductions in the area of arable land and an increasing population. Lu (1997) and Zhang (1997) argued that under current land conversion plans, food shortages may occur only in areas where food demand and supply are currently closely balanced or where food security risks already exist. Dong et al. (2005) compared food security with and without land conversion, and found that in Guyuan District the grain supply was more secure for farmers who participated in the SLCP than those who did not, because farmers were compensated for their converted land in the form of grains and cash. However, they also found that local production should be improved to ensure long-term food security. Xi \& Cao (2008) studied land use in China's loess plateau and found that at a lower per capita grain consumption level (e.g., $190 \mathrm{~kg}$ year ${ }^{-1}$ ), the current rate of arable land conversion would not jeopardize food security by 2010 , but if per capita food demand increases to $230 \mathrm{~kg}$ year $^{-1}$, food shortages would occur. Therefore, both food demand and production should be considered when tackling food security issues.

Our scenario analysis quantified the consequences of policies that directly or indirectly affect land-use change decisions and agricultural production by accounting for land-use change and changes in grain demand from the increasing population. It therefore provides valuable information to facilitate both systematic management of the existing land resources and planning and policy development for future arable land conversion directions and target quantities of each land use. Moreover, it reveals the trade-offs between conservation policies and food security in a sensitive region of China.

\section{Methodology}

The DLS approach provides an effective framework for simulating the dynamics of a land-use system. However, it should be noti- 
ced that the simulation results are not mean to predict the actual future land use; instead, they are projections designed to explore the impacts of assumed scenario conditions by allowing researchers to quantitatively visualize the results of scenario descriptions (Verburg et al. 2006). Analysis of the driving factors responsible for land-use change is a significant part of the DLS approach, in which the influencing factors are aggregated and processed at a pixel level, and then estimated by means of spatial regression analysis. In the present study, all variables were resampled to a pixel size of $300 \times 300 \mathrm{~m}$ before performing the regression analysis. This may be problematic because some variables (e.g. climatic and socioeconomic variables) have a very different original resolution. Climatic and socioeconomic variables are derived from the station or counties, so there are some errors when allocated into the grid pixel level. However, such error cannot be avoided if the regression analysis is carried out at the pixel level.

The validity of a model is mainly determined by the specific characteristics of the case study and by the quality of the input data (Verburg et al. 2006). Using 2010 data from Chinese statistical yearbooks (National Bureau of Statistics 2010), we compared actual grain production in Guyuan District with the values predicted in our baseline scenarios. We found that our estimate in the moderategrowth baseline scenario was within $5 \%$ of the actual values. This suggests that our modeling approach is reasonable and should be refined in future research to provide even better estimates. However, the uncertainty resulting from reducing the complexity in herent in land-use systems could be reduced by supplying a more flexible interface allowing the users to input spatial regression results by means of more robust model specification and by developing more than one kind of scenario to simulate the dynamics of landuse systems under various conditions.

\section{Visualization and decision support}

The visualization of land use trajectories for different scenarios can support policy discussions about the future land-use patterns in Guyuan District specifically, and for all of China more generally, by supporting the identification of priority areas for intervention and by testing the potential consequences of certain policy options. Our comparison of the results for the baseline and conservation policy scenarios in the presen study revealed that the area of arable land will decrease and the areas of forest and grassland will increase. This is likely to become an important issue in terms of the region's food security. Many studies in western China indicated that such land-use changes are common (Lin \& Samuel 2003, Feng et al. 2005, Uchida et al. 2004, Yang
2006). From the results of this study, we can provide the following advices to the local decision makers to ensure food security while conserving the natural environment:

1. Population control: population natural growth rate in the study area is $1.18 \%$, which is higher than the national average $(0.479 \%$ - SBGC 2011), it is thus important to continue population control policy.

2. Strict restrictions on occupation of arable land by other uses, in order to protect basic farmland areas.

3. Increase government investment in agricultural R\&D for increasing total production through improved crop varieties and cultivation techniques.

4. Strengthening the monitoring and management of grassland and forestland converted from arable land, so that the natural environment could be conserved and farmers income from forest products can be increased.

\section{Conclusions}

Between 2010 and 2020, the land-use dynamics in Guyuan District will be characterized by a decrease in the area devoted to agriculture and an increase in forest and grassland cover, accompanied by urban expansion. The increased areas of forest and grassland are distributed mostly in the central mountains of the district, and most of the new urban development is concentrated in downtown and residential areas, where most of the infrastructure and economic opportunities are located. The area of agricultural land has fluctuated over the past 20 years, but has only decreased regularly since implementation of the SLCP in 2000 in Guyuan district, after which a $9.3 \%$ reduction in the area of agricultural land was observed from 2000 to 2005 . For the other major land use types from 1986 to 2000, the areas of forest, urban, and unused land increased by 8.0 , 8.7 , and $6.0 \%$, respectively, but the area of grassland decreased by $8.1 \%$. As the urban population increased from $6.6 \%$ of the total in 1989 to $12.3 \%$ in 2007 (DPS 1991, OGC 2007), the area of urban land also increased. The implementation of the SLCP since 2000 has been the major process that has permitted the expansion of the areas of forest, grassland, and urban land.

Our study considered the predicted grain yield (including winter wheat, spring-sown maize, millet, buckwheat, and potatoes) in the scenario analysis, revealing a severe grain deficiency by the end of the simulation period (2020) under both the baseline scenarios and the conservation policy scenarios; such effect will be more severe under the high-growth scenarios and in the conservation scenarios. Therefore, food security is at risk in Guyuan District. However, decision makers could take some strategies to protect the region's food security, the main recom- mendations include control of population growth, increase investment in agricultural $\mathrm{R} \& \mathrm{D}$, improvement in monitoring and management of grass and forest, and strict protection of basic farmland.

Our scenario analysis quantified the consequences of policies that directly or indirectly affect land-use change decisions and agricultural production. Thus, they provide valuable information to support systematic management of the existing land resources and planning and policy development to guide future arable land conversion directions and the target quantities of each primary land use, and reveal the trade-offs between conservation policies and food security in a sensitive region of China.

\section{Acknowledgments}

This research was funded by the "Key Project for the Strategic Science Plan in IGSNRR of CAS (No. 2012ZD007), Technical Support Program of the Ministry of Science and Technology of China (No. 2013BAC 03B04), and the Ten Year's Ecoenvironment Assessment Project of MOST (STSN-14-00, National Key Project for Basic Research no. 2014CB95430201). We extend our heartfelt thanks to Geoff Hart for his assistance with the English language and for other valuable comments.

\section{References}

Belsky JM, Siebert SF (2003). Cultivating cacao: Implications of sun-grown cacao on local food security and environmental sustainability. Agriculture and Human Values 20: 277-285. - doi: 10.1023/A:1026100714149

Brown LR (1995). Who will feed China? Wakeup call for a small planet. WW Norton\& Company, New York, USA, pp. 163.

Caradec Y, Lucas S, Vidal C (1999). Agricultural landscapes: over half of Europe's territory maintained by farmers. European Commission's Directorate General for Agriculture and Rural Development, web site. [online] URL: http://ec. europa.eu/agriculture/envir/report/en/terr_en/rep ort.htm

CCICED (2004). China's agricultural and rural development in the new era: challenges, opportunities and policy options' policy recommendations and executive summary. China Council for International Cooperation on Environment and Development, Center for Chinese Agricultural Policy, Chinese Academy of Sciences, Beijing, China, pp. 23. [in Chinese with English summary] [online] URL: http://www.cciced.net/encciced/policyresearch/report/201205/

CDRG (2007). 11-12 ${ }^{\text {th }}$ five-year development plan of Guyuan district. Commission of Development and Reform of Guyuan, Ningxia Hui Autonomous Region, Guyuan, China, pp. 35. [in Chinese with English summary]

Chen CC (2008). Study on the ecosystem carrying capacity in Jinghe River Basin. PhD Dissertation, Graduate University of Chinese Academy 
of Sciences, Beijing, China, pp. 184. [in Chinese with English summary]

Corona P, Barbati A, Tomao A, Bertani R, Valentini R, Marchetti M, Fattorini L, Perugini L (2012). Land use inventory as framework for environmental accounting: an application in Italy iForest 5: 204-209. - doi: 10.3832/ifor0625-005

Deng XZ, Su HB, Zhan JY (2008). Integration of multiple data sources to simulate the dynamics of land systems. Sensors 8: 620-634. - doi: $10.3390 / \mathrm{s} 8020620$

Dong M, Zhong FN, Wang GJ (2005). An empirical study on grain for grass and food security in less developed regions: a case study of Ningxia Hui Autonomous region. China Population, Resources and Environment 15 (1): 104-108. [in Chinese with English summary]

DPS (1991). China population statistics yearbook 1990. Department of Population Statistics, National Bureau of Statistics of China, Scientific and Technical Documents Publishing House, Beijing, China, pp. 771. [in Chinese with English summary]

Du SF (2001). Environmental economics. Encyclopedia Press, Beijing, China, pp. 102. [in Chinese with English summary]

Feng ZM, Li XL (2000). The stratagem of cultivated land and food supplies security: storing food in land - raising the comprehensive productivity of land resource of China. Geography and Territorial Research 16 (3): 1-5. [in Chinese with English summary]

Feng ZM, Zhang PT, Song Y (2002). Food security: the impact of land conversion from farmland to forest or grassland on grain production in Northwest China. Journal of Natural Resources, 17 (3): 299-306. [in Chinese with English summary]

Feng ZM, Yang YZ, Zhang YQ, Zhang PT, Li YQ (2005). Grain-for-green policy and its impacts on grain supply in West China. Land Use Policy 22 (4): 301-312. - doi: 10.1016/j.landusepol.2004 05.004

Hao SL, Cheng BC, Zhao XM, Yu Q (2005). Dynamic analysis on the spatial pattern of landscape of small watershed in loess hilly-gully region: a case study of Shanghuang test area in Guyuan. Science of Soil and Water Conservation 3 (2): 107-112. [in Chinese with English summary]

Helming K, Tscherning K, Koenig B, Sieber S, Wiggering $\mathrm{H}$, Kuhlman $\mathrm{T}$, Wascher $\mathrm{D}$, PerezSoba M, Smeets P, Tabbush P, Dilly O, Huttl R, Bach H (2008). Ex ante impact assessment of land use changes in European regions - the SENSOR approach. In: "Sustainability Impact Assessment of Land Use Changes" (Helming K, Perez-Soba M, Tabbush P eds). Springer-Verlag, Berlin, Germany, pp. 77-105.

Huang JK, Deng XZ, Rozelle S (2004). Cultivated land conversion and bioproductivity in China. In: "Remote sensing and modeling of ecosystems for sustainability" (Gao W, Shaw R eds). Proceedings of the SPIE, Bellingham, Washington, DC, USA, pp. 135-148.

Jiang T, Shi YF (2003). Global climatic warming, the Yangtze floods and potential loss. Advances in Earth Sciences 18 (2): 277-284. [in Chinese with English summary]

König HJ, Zhen L, Helming K (2012). Assessing the impact of the sloping land conversion program on rural sustainability in Guyuan, western China. Land Degradation \& Development (early view). - doi: 10.1002/ldr.2164

König HJ, Uthes S, Schuler J, Zhen L, Purushothaman S, Suarma U, Sghaier M, Makokha S, Helming K, Sieber S, Chen L, Brouwer F, Morris J, Wiggering H (2013). Regional impact assessment of land use scenarios in developing countries using the FoPIA approach: findings from five case studies. Journal of Environmental Management 127: 556-564. - doi: 10.1016/j.jenvman.2012.10.021

König HJ, Podhora A, Helming K, Zhen L, Wang Z, Wübbeke J, Baumeister T, Du B, Yan H (2014). Confronting international research topics with local stakeholder perspectives on multifunctional land use: the case of Inner Mongolia, China. iForest (early view) - doi: 10.3832/ifor 11 72-007

Li AT (1999). 1998 Yangtze flood and fight against it. Yangtze River 30 (1): 1-7. [in Chinese with English summary]

Lin GCS, Samuel PSH (2003). China's land resources and land-use change: insights from the 1996 land survey. Land Use Policy 20: 87-107. doi: 10.1016/S0264-8377(03)00007-3

Liu JY, Liu ML, Deng XZ, Zhuang DF, Zhang ZX, Luo D (2002). The land-use and land-cover change database and its relative studies in China. Journal of Geographical Sciences 12 (3): 275282. - doi: 10.1007/BF02837545

Lu DD (1997). Report on regional development of China. Commercial Press, Beijing, China, pp. 333. [in Chinese with English summary]

Mander U, Helming K, Wiggering H (2007). Multifunctional land use: meeting future demands for landscape goods and services. In: "Multifunctional land use: meeting future demands for landscape goods and services" (Mander U, Wiggering $\mathrm{H}$, Helming $\mathrm{K}$ eds). Springer, Berlin, Germany, pp. 1-13.

Ministry of Land and Resources (2004). Regulation on implementing protection of cultivated land nationwide. Beijing, China, pp. 38. [in Chinese with English summary]

National Bureau of Statistics (2010). Statistic Year Book of China. China Statistic Press, Beijing, China, pp. 1032. [in Chinese]

OGC (2007). Guyuan yearbook 2007. Office of Guyuan Chorography, Chinese Cultural and Historical Press, Beijing, China, pp. 443. [in Chinese with English summary]

Parés-Ramos I, Gould W, Aide TM (2008). Agricultural abandonment, suburban growth, and forest expansion in Puerto Rico between 1991 and 2000. Ecology and Society 13 (2): 1. [online] URL: http://www.ecologyandsociety.org/vol13/ iss $2 / \operatorname{art} 1 /$

Ramankutty N, Foley JA, Olejniczak NJ (2002). People on the land: changes in global population and croplands during the $20^{\text {th }}$ century. Ambio 31
(3): 251-257. [online] URL: http://www.ncbi. nlm.nih.gov/pubmed/12164136

SBGC (2011). Report of the $6^{\text {th }}$ population census of Guyuan. Statistical Bureau of Guyuan City, Guyuan city of Ningxia Hui Autonomous Region, China, pp. 38. [in Chinese with English summary]

State Council (1998). Circular for conservation of forest resources and prohibition of deforestation and occupation of forest land. State Council, Beijing, China, pp. 2. [in Chinese with English summary]

Tan S, Peng B (2003). Examination of cultivated land utilization to guarantee our grain security and its recent adjustment thoughtfulness. Economic Geography 23 (3): 371-374. [in Chinese with English summary]

Tao R, Xu ZG, Xu JT (2004). Grain for green project, grain policy and sustainable development. Social Sciences in China 6: 25-38. [in Chinese with English summary]

Thapa GB, Rasul G (2006). Implications of changing national policies on land use in the Chittagong Hill Tracts of Bangladesh. Journal of Environmental Management 81 (4): 441-453. - doi: 10.1016/j.jenvman.2005.12.002

Turner BL, Moss RH, Skole D (1993). Relating land use and global land-cover change: a proposal for an IGBP-HDP core project. IGBP Report No. 24/HDP Report No. 5, International Geosphere-Biosphere Programme, Stockholm, Sweden, pp. 65. [online] URL: http://www.ciesin. org/

Uchida E, Rozelle S, Deng XZ, Huang JK (2004). Changes in cultivated land due to urbanization: China in an international perspective. CCAP Working Paper, Paper Presented in CCICED, Agricultural and Rural Development Working Meeting, Center for Chinese Agricultural Policy, Chinese Academy Sciences, Beijing, China, pp. 56

Verburg PH, Chen YQ, Veldkamp TA (2000). Spatial explorations of land use change and grain production in China. Agriculture, Ecosystems \& Environment 82: 333-354. - doi: 10.1016/S01678809(00)00236-X

Verburg PH, Soepboer W, Veldkamp A, Limpiada R, Espaldon V (2002). Modeling the spatial dynamics of regional land use: the CLUE-S model. Environment Management 30: 391-405. - doi: 10.1007/s00267-002-2630-x

Verburg PH, Schulp CJE, Witte N, Veldkamp TA (2006). Downscaling of land use change scenarios to assess the dynamics of European landscapes. Agriculture, Ecosystems \& Environment 114: 39-56. - doi: 10.1016/j.agee.2005.11.024

Wang WG, Pang XX, Song YX, Li RZ (2012). The spatial differential features of construction land changes in China. Areal Research and Development 31 (1): 110-115. [in Chinese with English abstract] [online] URL: http://en.cnki. com.cn/Article en/CJFDTOTAL-DYYY201201 022.htm

Xi J, Cao MM (2008). Grain-for-Green program and its impacts on food security in hilly and gully area of Loess plateau in northern Shaanxi 
province: take Mizhi county in Yulin city as a case. Journal of Arid Land Resources and Environment 22 (8): 165-169. [in Chinese with English summary]

Xu JT, Cao YY (2001). Converting steep cropland to forest and grassland: efficiency and prospects of sustainability. International Economic Review 2: $56-60$.

Xu ZG, Bennett MT, Tao R, Xu JT (2004). China's sloping land conversion programme four year on: current situation and pending issues. International Forestry Review 6: 317-327. - doi 10.1505/ifor.6.3.317.59976

Yang H, Li XB (2000). Cultivated land and food supply in China. Land Use Policy 17: 73-88. doi: 10.1016/S0264-8377(00)00008-9

Yang L, Xie GD, Zhen L, Leng YF, Guo GM (2005). Spatio-temporal changes of land use in Jinghe watershed. Resources Science 27(4): 2632. [in Chinese with English summary] [online] URL: http://en.cnki.com.cn/Article_en/CJFDTO TAL-ZRZY200504005.htm
Yang L (2006). Landscape pattern changes and driving force analysis in Jinghe Watershed. $\mathrm{PhD}$ Dissertation, Graduate University of Chinese Academy of Sciences, Beijing, China, pp. 108. [in Chinese with English summary]

Zhang LC, Wu CC (1997). The forecast of the regional pattern changes in China's grain production in the early $21^{\text {st }}$ century. National Territory and Land Economics 1: 16-19. [in Chinese with English summary]

Zhang RY, Yang XL (1998). History and brief analysis of drying up in Yellow River. Yellow River 20 (10): 38-40. [in Chinese with English summary]

Zhang XB, Jiang SL, Shangguan ZP, Wang LX, Liu B (2006). Study on the eco-agriculture construction and sustainable development in Jinghe watershed. Agricultural Research in the Arid Areas 24 (3): 138-142. [in Chinese with English summary]

Zhen L, Cao S, Cheng S, Xie G, Wei Y, Liu X, Li F (2010). Arable land requirements based on food consumption patterns: Case study in rural Guyuan District, Western China. Ecological Economics 69 (7): 1443-1453. - doi: 10.1016/j. ecolecon.2008.12.008

Zhen L, Cao S, Wei Y, Dilly O, Liu X, Li F, Koenig H, Tscherning K, Helming K (2009). Comparison of sustainability issues in two sensitive areas of China. Environmental Science \& Policy 12 (8): 1153-1167. - doi: 10.1016/j.env sci.2009.03.002

Zhen L, Xie GD, Yang L, Cheng SK (2007). Land use dynamics, farmers' preference and policy implications in the Jinghe watershed of remote Northwestern China. Outlook on Agriculture 32 (2): 127-135. - doi: 10.5367/000000007781159 921

Zhen L, Xie GD, Yang L, Cheng SK, Guo GM (2005). Land-use change dynamics, driving forces and policy implications in Jinghe watershed of Western China. Resources Science 27 (4): 33-37. [in Chinese with English summary] 